філології. Серія: Лінгвістика і літературознавство: зб. наук. пр. 2009. Вип. ХХ. С. 402-411.

5. Рудницька О.П. Українське мистецтво у полікультурному просторі: Навчальний посібник. Київ, $2000.208 \mathrm{c}$.

6. Сухомлинський В. О. Вогнегривий коник: казки, притчі, оповідання /Упоряд. іпередм. О.В. Сухомлинський. Київ, 2007. 200 с. : іл.

\section{REFERENCES}

1. Vernyhora, N. M. Rol periodychnykh vydan dlia ditei $\mathrm{u}$ formuvanni movnykh navychok [The role of periodicals for children in the formation of language skills]. Available at: http://journlib.univ.kiev.ua/index.php?act $=$ article \&article $=2052$. [in Ukrainian].

2. Davydchenko, T. S. (2008). Typolohichna klasyfikatsiia dytiachykh periodychnykh vydan v Ukraini [Typological classification of the children's periodicals in Ukraine]. Scientific notes of the Institute of Journalism: scientific collection. (Ed.).V. V. Rizun. Kyiv, Vol. 30, pp. 116-120.[in Ukrainian].
3. Kolobochok. Dlia rozumnykh ditochok. Shchomisiachnyi piznavalnyi zhurnal dlia ditei $3-9$ rokiv (2015).[Kolobochok For smart kids. Monthly Cognitive Magazine for Children aged 3-9]. No. 1-12. 24 p. [in Ukrainian].

4. Krul, L. M. \& Blahun, N. M. (2009). Zahalnyi ohliad suchasnoi ukrainskoi dytiachoi periodyky (zhanrovo-tematychne rozmaittia) [An overview of modern Ukrainian children's periodicals (genre and thematic diversity)]. Actual problems of Slavic philology. Series: Linguistics and Literature: A collection of scientific works. Vol. 20, pp. 402-411. [in Ukrainian].

5. Rudnytska, O.P. (2000). Ukrainske mystetstvo u polikulturnomu prostori: navchalnyi posibnyk [Ukrainian art in the multicultural space: tutorial]. Kyiv, 208 p. [in Ukrainian].

6. Sukhomlynskyi, V. O. (Ed.). (2007). Vohnehryvyi konyk: kazky, prytchi, opovidannia [Gunpowder grasshopper: fairy tales, parables, stories]. Kyiv, 200 words illustrated.

Стаття надійшла до редакції 15.04.2019

УДК 373.2.015.31:613

DOI:

Марина Орлова, аспірант кафедри соціальної роботи Національного університету “Чернігівський колегіум” імені Т.Г. Шевченка

\title{
ОРГАНІЗАЦІЙНО-ПЕДАГОГІЧНІ УМОВИ ЗБЕРЕЖЕННЯ ЗДОРОВ'Я ДІТЕЙ ДОШКІЛЬНОГО ВІКУ
}

У статті визначено та охарактеризовано організаиійно-педагогічні умови здоров 'язбереження дітей дошкільного віку. Теоретичний аналіз наукової літератури з окресленої теми дозволив визначити такі умови здоров'язбереження дітей дошкільного віку: поєднання засвоєння дітьми знань про власне здоров 'я, иіннісне ставлення до нього та формування здорового способу життя з руховою активністю дітей; використання в закладах дошкільної освіти сучасних здоров 'язбережувальних педагогічних технологій; взаємодія сім'ї та закладу дошкільної освіти щодо здоров 'язбереження дітей.

Ключові слова: здоров'я; здоров'язбереження; дитина дошкільного віку; рухова активність; заклад дошкільної освіти; сім'я; педагогічна технологія.

Jim. 5.

Maryna Orlova, Postgraduate Student of the Social Work Department Taras Shevchenko "Chernihiv Collegium" National University

\section{ORGANIZATIONAL AND PEDAGOGICAL CONDITIONS OF PRESERVING THE HEALTH OF PRESCHOOL CHILDREN}

The article highlights the problem of preserving the children's health as an important task of modern Ukrainian society. The health is a complicated phenomenon of global significance, which includes a complex of social, economic, biological, medical aspects and serves as an object of consumption, capital investment, individual and social value, a social phenomenon, dynamic, constantly associated with the physical and social environment. Another definition, adopted by the World Health Organization, is widely known: this is a state of complete physical, mental and social well-being and not merely the absence of disease and physical defects.

The organizational and pedagogical conditions of preserving health of children of preschool age are defined and characterized in the article. Theoretical analysis of the scientific literature on this topic allowed us to define the following terms of preserving preschool children's health: the combination of learning knowledge about their own health, the value of the attitude towards it and the formation of a healthy lifestyle with motor activity of children; the use of the modern pedagogical technologies of health preserving in the institutions of the preschool education; the interaction between the family and the establishment of early childhood education for preserving children's health. 


\section{ОРГАНІЗАЦЙНО-ПЕДАГОГІЧНІ УМОВИЗБЕРЕЖЕННЯ ЗДОРОВ'Я ДІТЕЙ ДОШКІЛЬНОГО ВІКУ}

The author draws attention to the use of pedagogical technologies of health's preserving in the educational activities. The pedagogical technologies of health's preserving is a complex of modern forms, methods, substantive components of the children's education, relating to the preservation and strengthening of their health, improvement of the conditions of learning, gaming activities, recreation, life. The solving of the problem of preserving preschool children's health requires a comprehensive and systematic approaches, the creation and observance of a number of organizational and pedagogical conditions, aimed at the organization of system activity of preserving children's health in the institutions of the pre-school education, which covers all areas of the child's life: a family and the peer group, learning, games, resting, nutrition.

Keywords: health; preservation of the health; a child of preschool age; motional activity; an establishment of early childhood education; a family; an educational technology.

П остановка проблеми. Збереження здоров’я дітей - важливе завдання сучасного українського суспільства, бо без його виконання неможливий подальший поступ нашої країни як демократичної європейської держави. Піклування про здоров'я дитини з боку дорослих має відбуватися в усіх сферах ii життєдіяльності: у родині, в закладі освіти, в середовищі однолітків. У Законі України "Про освіту" (2017) зазначається, що "освіта $€$ основою інтелектуального, духовного, фізичного і культурного розвитку особистості, ïï успішної соціалізації, економічного добробуту, запорукою розвитку суспільства, об'єднаного спільними цінностями і культурою, та держави. Метою освіти $\epsilon$ всебічний розвиток людини як особистості та найвищої цінності суспільства, іiі талантів, інтелектуальних, творчих і фізичних здібностей, формування цінностей і необхідних для успішної самореалізації компетентностей, виховання відповідальних громадян, які здатні до свідомого суспільного вибору та спрямування своєї діяльності на користь іншим людям і суспільству, збагачення на цій основі інтелектуального, економічного, творчого, культурного потенціалу Українського народу, підвищення освітнього рівня громадян задля забезпечення сталого розвитку України та їі європейського вибору" [2]. Таке тлумачення суспільного змісту та місії освіти актуалізує й завдання здоров'язбереження дітей.

Аналіз основних досліджень. Дослідження різних аспектів проблеми формування та збереження здоров'я дітей висвітлені у працях видатних українських і зарубіжних педагогів Я.А. Коменського, Ж.-Ж. Руссо, В. Сухомлинського, К. Ушинського та сучасних учених С. Грищенко, О. Дубогай, М. Носка та ін.

Метою пропонованої статті $\epsilon$ визначення та характеристика організаційно-педагогічних умов збереження здоров'я дітей дошкільного віку.

Виклад основного матеріалу дослідження. Насамперед, наголосимо, що у науковому обігу досить широко використовується визначення здоров'я, окреслене в преамбулі Статуту
Всесвітньої організації охорони здоров'я (1948): “ЗДдоров’ я - це стан повного фізичного, духовного і соціального благополуччя, а не лише відсутність хвороб або фізичних вад” $[1,318]$.

В “Енциклопедії освіти” (2008) зазначається, що здоров'я - це динамічний стан організму людини, який характеризується високим енергетичним потенціалом, оптимальними адаптаційними реакціями на зміни довкілля, що забезпечує гармонійний фізичний, психоемоційний і соціальний розвиток особистості, їі активне довголіття, повноцінне життя в соціумі, ефективну протидію захворюванням [1, 318].

Збереження здоров'я дітей є складною проблемою, тому для її вирішення мають бути залучені як освітні, так i, загалом, різноманітні соціальні засоби. Така соціально-педагогічна діяльність, спрямована на збереження здоров'я дітей, має розпочинатися ще до їх народження i охоплювати сім'ю, заклади дошкільної освіти, державні та громадські установи.

Згідно з Законом України “Про освіту” (2017), метою дошкільної освіти є забезпечення цілісного розвитку дитини, іiї фізичних, інтелектуальних і творчих здібностей шляхом виховання, навчання, соціалізації та формування необхідних життєвих навичок [2]. Для реалізації цієї мети необхідні пошуки нових підходів до організації та змісту виховання дітей дошкільного віку, зокрема у ньому обов'язково мають бути враховані завдання формування, збереження та зміцнення здоров'я.

Складний процес здоров'язбереження дітей дошкільного віку вимагає створення та дотримання низки організаційно-педагогічних умов. Теоретичний аналіз наукової літератури 3 окресленої теми дозволив визначити такі умови здоров'язбереження дітей дошкільного віку: поєднання засвоєння дітьми знань про здоров'я, ціннісне ставлення до власного здоров'я та формування здорового способу життя з руховою активністю дітей; використання в закладах дошкільної освіти сучасних здоров' язбережувальних педагогічних технологій; взаємодія сім’ї та закладу дошкільної освіти у напрямі здоров'язбереження дітей. 
Насамперед, розпочнемо характеристику першої умови здоров'язбереження дітей.

Засвоєння дітьми елементарних знань і уявлень про власне тіло, про свій організм, про складники здоров'я, його формування та збереження має відбуватися в цікавих формах, що містять читання та обговорення казок, елементи ігор, бесід, реальних і віртуальних екскурсій, організованих вихователями 3 освітньою метою, демонстрацію та обговорення ілюстрацій, які мають відповідну тематику, демонстрацію та обговорення ілюстрацій, які мають відповіднутематику. Окрім цього, діяльність вихователів щодо засвоєння знань про здоров'я і усвідомленого ставлення до власного здоров'я у дітей дошкільного віку передбачає розкриття істотних зв'язків і залежностей, які існують між станом здоров'я людини та ії способом життя, тому значну увагу під час таких занять варто приділяти розумінню сутності здорового способу життя та шляхів його формування.

Важливо, щоб нові знання відповідали віку дітей і були доступними для сприйняття ними.

Для становлення всебічно розвиненої, здорової особистості такі заняття повинні поєднуватися 3 руховою активністю дітей, що може реалізовуватися у формі рухливих ігор, занять гімнастикою, плаванням тощо. Основою занять 3 рухової активності дітей дошкільного віку можуть стати як відповідні сучасні педагогічні технології, так і досвід української народної педагогіки, пов'язаний 3 іграми, забавками, елементами танців.

В русі, наприклад під час освітніх екскурсій або ігор на свіжому повітрі, дитина ознайомлюється 3 навколишнім середовищем, задовольняючи свої природні потреби в пізнанні, в спілкуванні з однолітками, в розвитку кінетичних та інших здібностей.

На нашу думку, саме поєднання елементарних (відповідно віку дітей) занять, спрямованих на формування знань про здоров'я, з руховою активністю дошкільнят $\epsilon$ обов'язковою умовою здоров'язбереження дітей.

Друга умова здоров'язбереження дітей за своїм змістом логічно доповнюю попередню умову і полягає в доцільності використання в закладах дошкільної освіти сучасних здоров' язбережувальних педагогічних технологій.

Здоров'язбережувальні педагогічні технології - це сукупність принципів, методів, форм і засобів пізнавальної, ігрової або іншої діяльності дітей, що забезпечує зміцнення та збереження їх здоров’я.

До здоров'язбережувальних технологій вчені відносять:
- сприятливі умови перебування та навчання дитини в закладі освіти (відсутність стресових ситуацій, адекватність вимог, методик навчання та виховання);

- оптимальну організацію освітнього процесу (відповідно до вікових, статевих, індивідуальних особливостей та гігієнічних норм);

- повноцінний та раціонально організований руховий режим.

Слід зазначити, що впровадження здоров'язбережувальних освітніх технологій пов'язано 3 використанням медичних (медикогігієнічних, фізкультурно-оздоровчих, лікувальнооздоровчих), соціально-адаптуючих, екологічних технологій та технологій забезпечення безпеки життєдіяльності $[5,6]$.

Деякі вчені вважають, що під здоров'язбережувальними освітніми технологіями треба розуміти всі педагогічні технології, які не шкодять здоров'ю дітей $[5,7]$. Але не шкодити здоров'ю замало, необхідно, щоб педагогічні заходи, що використовуються в закладах освіти, зміцнювали здоров'я дітей.

До сучасних здоров'язбережувальних технологій, які доцільно використовувати в закладах дошкільної освіти у процесі навчання, виховання та розвитку дітей, фахівці відносять арт-терапію, фітбол-гімнастику, музикотерапію, казкотерапію тощо [4, 418].

Арт-терапія - це сукупність методів і прийомів психічного “зцілення” людини за допомогою занять будь-яким видом мистецтва. Але, якщо мова йде про дітей дошкільного віку, тоді функції арт-терапії стають пізнавальними, профілактичними та здоров'язбережувальними.

Як зазначають сучасні науковці, арт-терапія забезпечує позитивний ефект завдяки можливостям, що зцілюють, саме художню творчість, що дозволяє виразити і знову пережити внутрішні конфлікти. Самореалізація особистості дитини через почуття та емоції відбувається більш продуктивно в усіх сферах життєдіяльності i тому збагачення дитини досвідом емоційних відносин до навколишнього світує найважливішим аспектом духовного розвитку дитини - ii духовного здоров'я [4, 418].

Дуже популярною сьогодні у закладах дошкільної освіти стала фітбол-гімнастика як технологія, що, з одного боку, сприяє фізичному розвитку дітей і зміцненню їх здоров'я, а, з іншого, - викликає їх інтерес, задоволення та радість від ігрових занять 3 м'ячем. Фітбол-гімнастика одна 3 нетрадиційних форм роботи 3 дітьми. Фітбол (Fitball) у перекладі з англійської мови означає “м'яч для опори”, застосовується 3 
оздоровлювальною метою [4, 418]. Це фізичні або ігрові вправи, які виконують діти на великому м'ячі, спираючись, лягаючи на нього тощо.

Виконання дітьми вправ фітбол-гімнастики на великих м'ячах сприяє зміцненню різних груп м'язів, корекції фігури, тренуванню дихальної системи, формуванню правильної постави, покращенню фізичних якостей: координації, сили, загальної витривалості, гнучкості, рівноваги; удосконаленню техніки виконання різноманітних видів основних рухів; розвитку креативних здібностей у руховій сфері. У закладах дошкільної освіти України використовується фітболгімнастика за методикою відомої української гімнастки Катерини Серебрянської [5, 29].

Однією із сучасних педагогічних здоров'язбережувальних технологій $\epsilon$ музикотерапія, тобто контрольоване використання музики в освіті, вихованні, лікуванні та реабілітації дітей [4, 419]. Музикотерапія активно використовується в корекції емоційних відхилень, страхів, рухових і мовних розладів, відхилень у поведінці, при комунікативних труднощах.

Музика здатна встановлювати загальний настрій дитини. Під ii впливом розвивається художнє сприйняття дитини, багатшими стають переживання. Немає дітей абсолютно байдужих до музики. Отже, в процесі слухання музики розвиваються позитивні риси: (упевненість, чесність, сміливість, доброта тощо), проходять невротичні прояви (страхи, тривожність, невпевненість тощо). Таким чином, активно беручи участь в музикотерапевтичному сеансі, дитина виражає себе, свій емоційний стан співом, рухом, грою на інструменті, приводить до вирішення внутрішнього конфлікту i, як наслідок, до стабілізації психоемоційного стану [4, 419].

У здоров'язбережувальних технологіях, розроблених на засадах музикотерапії для дітей дошкільного віку, на нашу думку, доцільно поєднувати музику з руховою активністю дітей: танцювальними, ритмічними вправами або рухливими іграми.

Казкотерапія - це виховання і лікування казкою. Казка не тільки вчить дітей переживати, радіти, співчувати, сумувати, але і спонукати їх до мовного контакту. Це найбільш ефективний засіб коректувальної дії на дитину, в якій найяскравіше виявляється принцип навчання: вчити граючи [4, 419].

Казкотерапія $\epsilon$ найбільш ефективною технологією для роботи з дітьми дошкільного віку. Ефективність використання казкотерапії в дошкільному віці забезпечується специфікою діяльності дитини в цьому віці, а також привабливістю цього жанру, що дозволяє вільно мріяти і фантазувати. За допомогою казкових образів, їх дій, дитина може знайти вихід з різних складних ситуацій, побачити шляхи вирішення конфліктів, засвоїти моральні норми і цінності, розрізняти добро і зло [4, 419].

У якості однієї з методик казкотерапії можна використовувати постановку (інсценування) казок. За таких умов відбувається всебічний розвиток дитини, томущо діти не тільки розвиваються інтелектуально, співпереживають героям казки, уявлять їх, їхню поведінку, ай рухаються, демонструють образи героїв казок мовою рухів, жестів.

Отже, сучасні здоров'язбережувальні педагогічні технології, що використовуються в закладах дошкільної освіти, поєднують фізичний, розумовий, естетичний, моральний розвиток дітей і виконують завдання не тільки фізичного виховання, а й профілактики негативних явищ у дитячому середовищі та соціальної і психологічної адаптації дітей.

Перейдемо до характеристики третьої умови здоров'язбереження дітей дошкільного віку, сутність якої полягає у взаємодії закладу дошкільної освіти та сім’ї стосовно збереження здоров'я дітей.

У контексті дотримання окресленої умови перед вихователями закладів дошкільної освіти висуваються завдання: оцінювати та аналізувати рівень здоров'я, стан фізичного розвитку дошкільників; підняти на якісно новий рівень руховий режим дітей, використовуючи найдоцільніші засоби, форми й методи роботи в конкретних умовах; творчо підходити до організації освітнього процесу; передбачати бажаний рівень кінцевого результату; порівнювати досягнуті результати з вихідними та поставленими новими завданнями; створювати умови для самостійної рухової активності; здійснювати спільну роботу з батьками стосовно формування здорового способу життя в сім'ї [3, 13].

В організації освітньої роботи з формування здорового способу життя і фізичного виховання дошкільників вихователям необхідно враховувати закономірності фізичного, нервово-психічного розвитку, а також інтелектуальні можливості дітей. Таку інформацію педагоги можуть отримати, зокрема, й від батьків дітей.

Рівень фізичного розвитку та рухової підготовленості, стан здоров'я, самопочуття, вікові та індивідуальні особливості дітей мають ураховуватись, на думку сучасних учених, при дозуванні фізичних і психічних навантажень та під час планування фізкультурно-оздоровчої роботи, формування здорового способу життя [3, 13]. 
Для правильної організації заходів щодо забезпечення здорового способу життя та збереження здоров'я дітей необхідна співпраця вихователя 3 медсестрою, психологом для систематичного контролю за станом здоров'я дошкільників, профілактики та виявлення порушень у них, спостереження за загальним станом фізичного та психічного здоров'я, оптимальним руховим режимом, проведенням процедур загартування дітей, санітарно-гігієнічним станом місць організації занять, надто важливою $\epsilon$ просвітницька робота з батьками з питань організації та дотримання здорового способу життя дітей.

Формування здорового способу життя та збереження здоров'я дітей дошкільного віку передбачає спільну роботу педагогів з батьками, які $\epsilon$ прикладом поведінки, зразком для наслідування. У формі бесід, консультацій, практикумів батькам необхідно в доступній формі систематично пояснювати особливості формування здорового способу життя, ознайомлювати 3 віковими та психологічними особливостями дітей, порушувати питання їхнього здоров'я та фізичного розвитку, а також проведення дозвілля 3 користю для малюка $[3,13]$.

Доцільно запрошувати батьків до участі в просвітницьких і оздоровчих заходах, що проводяться в закладі дошкільної освіти, а саме: в батьківських зборах, консультаціях, бесідах, освітніх і виховних заняттях для дітей; Днях або Тижнях здоров'я, Днях відкритих дверей, туристичних походах, спортивних розвагах і змаганнях, почасти поступово перетворюючи заклад дошкільної освіти у відкриту соціальну систему, що пов'язана з сім'ями вихованців, закладами загальної середньої освіти, різними суспільними інституціями та громадою в цілому.

Для повноцінного розвитку дитини батькам слід створювати валеологічно обумовлені умови життєдіяльності, для харчування використовувати екологічно чисті, багаті на білки, вітаміни, мінеральні речовини, продукти, підтримувати порядок та гігієну в помешканні, регулярно купати, загартовувати, робити масаж, фізичні вправи, більше часу проводити на свіжому повітрі. Необхідно більше гратися 3 дитиною, спілкуватися, творчо підходити до формування основ здорового способу життя.

Щоб бути здоровою, людина повинна жити в гармонії із собою, світом, природою. Батьки мають вчити дитину з раннього віку любити себе, людей, природу, життя, виховувати позитивне ставлення до власного здоров'я як найбільшої цінності [3, 13].
Під час батьківських зборів, групових або індивідуальних консультацій, що проводяться в закладі дошкільної освіти, доцільно надавати батькам дошкільнят спеціально розроблені фахівцями рекомендації щодо збереження здоров'я дітей, профілактики різноманітних захворювань, шкідливих звичок, педагогічні поради, які стосуються різних аспектів виховання дітей залежно від їх віку, здібностей, особистісних і психічних характеристик.

На нашу думку, без взаємодії усіх фахівців закладу дошкільної освіти (педагогів, психологів, медиків) з батьками дітей завдання збереження та зміцнення здоров'я дітей неможливо реалізувати.

Висновки 3 даного дослідження та перспективи подальших розвідок. Отже, вирішення проблеми здоров'язбереження дітей дошкільного віку вимагає застосування комплексного й системного підходів, створення та дотримання низки організаційно-педагогічних умов, що спрямовані на організацію в закладах дошкільної освіти системної здоров' язбережувальної діяльності, яка охоплює усі сфери життєдіяльності дитини: родину та товариство однолітків, навчання, ігри, відпочинок, харчування. До таких умов ми відносимо: поєднання засвоєння дітьми знань про здоров' я, ціннісне ставлення до власного здоров'я та формування здорового способу життя 3 руховою активністю дітей; використання в закладахдошкільноїосвітисучаснихздоров'язбережувальних педагогічних технологій; взаємодія сім’ї та закладу дошкільної освіти щодо здоров’язбереження дітей.

Подальші дослідженняпроблемиздоров' язбереження дітей дошкільного віку можуть бути пов'язані 3 удосконаленням професійної підготовки педагогів до такої діяльності. Актуальними вважаємо науково обгрунтовані розробки соціальнопедагогічних програм, спрямованих на формування позитивної мотивації щодо правильного харчування, режиму дня, занять спортом, а також здорового способу життя дітей.

\section{ЛІТЕРАТУРА}

1. Енциклопедія освіти / голов. ред. В. Г. Кремень. Київ, 2008. 1040 с

2. Закон України “Про освіту”. URL: https:// ru.osvita.ua/legislation/law/2231/

3. Замрозевич-Шадріна С. Проблеми збереження та зміцнення здоров'я дітей дошкільного віку. Обрії. 2014. №2 (39). C. 12-14.

4. Погрібняк Н. В., Сремєєва М. С. Збереження фізичного і психічного здоров'я дітей дошкільного віку засобами арт-терапії. Педагогіка здоров'я : збірник наукових праць IV Всеукраїнської науково-практичної 
конференції, присвяченої 210-річчю з дня заснування Харківського національного педагогічного університету імені Г. С. Сковороди / за загальною редакцією акад. Прокопенка І. Ф. Харків, 2014. С. 417-421.

5. Сучасні технології збереження здоров'я учнів: кращий досвід / авт. кол. ; уклад. А. Г. Обухівська. Київ, $2015.221 \mathrm{c}$.

\section{REFERENCES}

1. Entsyklopediia osvity (2008). [Encyclopedia of education]. (ed.).V. H. Kremen. Kyiv, 1040 p. [in Ukrainian].

2. Zakon Ukrainy "Pro osvitu" (2014). [The law of Ukraine "About education"]. Available at: https:// ru.osvita.ua/legislation/law/2231/ [in Ukrainian].

3. Zamrozevych-Shadrina, S. (2014). Problemy zberezhennia ta zmitsnennia zdorovia ditei doshkilnoho viku [The problems of preservation and strengthening of health of preschool children]. Obrii. No. 2(39), pp. 12-14. [in Ukrainian].
4. Pohribniak, N. V. \& Yeremieieva, M. Ye. (2014). Zberezhennia fizychnoho i psykhichnoho zdorovia ditei doshkilnoho viku zasobamy art-terapii [The preserving of physical and mental health of preschool children by means of art therapy]. Pedahohika zdorovia : zbirnyk naukovykh prats IV Vseukrainskoi naukovo-praktychnoi konferentsii, prysviachenoi 210-richchiu z dnia zasnuvannia Kharkivskoho natsionalnoho pedahohichnoho universytetu imeni H. S. Skovorody - The education of health: scientific papers of the 4-th All-Ukrainian ScientificPractical Conference devoted to the 210-th anniversary of the founding of the G. S. Skovoroda Kharkiv National Pedagogical University. (pp. $417-$ 421). Kharkiv. [in Ukrainian].

5. Suchasni tekhnolohii zberezhennia zdorovia uchniv: krashchyi dosvid (2015). [Modern technologies of health students: best practices]. (Ed.). A. H. Obukhivska. Kyiv, 221 p. [in Ukrainian].

Стаття надійшла до редакції 28.03.2019

УДК 378.147.091.31-051:5

DOI:

Олена Блашкова, аспірант кафедри педагогіки та управління навчальним закладом Кам'янеиь-Подільського начіонального університету імені Івана Огієнка

\section{КЛЮЧОВІ КОМПЕТЕНТНОСТІ МАЙБУТНІХ ВЧИТЕЛІВ ПРИРОДНИЧИХ СПЕЦАЛЬНОСТЕЙ ТА ЇХ ВПЛИВ НА ФОРМУВАННЯ СВІТОГЛЯДНИХ ОРІЕНТИРІВ СУЧАСНОЇ СТУДЕНТСЬКОЇ МОЛОДІ}

У статті висвітлено пріоритетні компетентності майбутніх вчителів природничих спеціальностей та їх вплив на формування світоглядних орієнтирів сучасної студентської молоді. Акиентується увага на змісті ключових фахових компетентностей першого (бакалаврського) та другого (магістерського) рівнів підготовки студентів природничих специіальностей. Підкреслено, щ̧о формування гуманістичних иінностей $\epsilon$ важливим процесом становлення майбутніх учителів, як професіоналів.

Ключові слова: майбутні вчителі природничих спещіальностей; гуманістичні ціннісні орієнтири; ключові компетентності.

Лim. 13.

Olena Blaskova, Postgraduate Student of the Pedagogy and Management of Educational Institution Department Kamyanets-Podilskiy Ivan Ohiyenko National University

\section{KEY COMPETENCIES OF FUTURE TEACHERS OF NATURAL SCIENCES AND THEIR INFLUENCE ON THE FORMATION OF IDEOLOGICAL LANDMARKS OF MODERN STUDENTYOUTH}

Formulation of the problem. The article highlights the priority of special-subject competencies of the professional training of future teachers of natural sciences and the possibility of forming humanistic values during the educational process.

The relevance of the chosen theme is based on the fact that in the present time the reform of the pedagogical education of higher educational institutions and the implementation of the course of humanization and humanization of the educational process, based on personality-oriented, axiological, humanistic and competent approaches, contributes to the formation of humanistic values in the process of professional development of future teachers.

The purpose of the paper is to update the natural and ecological competencies in the process of forming humanistic values of the modern student youth of natural sciences.

Research methods. The search materials for writing the article were scientific articles, normative documents, educational-professional programs and curricula of specialties 014 Secondary education (Biology and human health); 014 Secondary education (Geography) and 101 "Ecology" of preparation of the first (Bachelor) and 